\title{
The Effect of Temperature on the Development of Bacterial Leaf Blight on Rice
}

\author{
Osamu Horino, ${ }^{*}$ Twing Wah MEW** and Toshiaki YamadA* \\ 堀野 修*.Twing Wah Mew**・山田利昭* : イネ白葉枯病の \\ 病斑進展に及ぼす温度の影響
}

Key Words : lesion development, temperature, bacterial leaf blight, rice.

The study was conducted to investigate the effect of temperature on the development of bacterial leaf blight caused by Xanthomonas campestris pv. oryzae. Five different temperatures (day/night) - $35 \mathrm{C} / 27 \mathrm{C}, 33 \mathrm{C} / 25 \mathrm{C}, 29 \mathrm{C} / 21 \mathrm{C}, 25 \mathrm{C} / 20 \mathrm{C}$ and $20 \mathrm{C} / 17 \mathrm{C}$ - set in growth cabinets or glasshouses at the IRRI phytotron with a $70 \%$ relative humidity were used. The plants were grown to the reproductive stage in the greenhouse and transferred into the phytotron 1 week before inoculation. Three japonica rice varieties (Kinmaze, Kogyoku and Asominori) and five indica rices (IR8, IR20, IR26, IR28 and Cas 209) were used in the growth cabinet experiment. In the glasshouse experiment, DV85 carrying the resistance genes $x a-5$ and $X a-7^{1)}$ was used in addition to the eight varieties. Four Philippine strains exemplified by PXO61 for group I, PXO86 for group II, PXO79 for group III, and PXO71 for group IV ${ }^{2}$ were used to inoculate plants in the glasshouse, at high $(35 \mathrm{C} / 27 \mathrm{C})$ and normal $(29 \mathrm{C} / 21 \mathrm{C})$ temperatures. PXO61 and PXO71 were also used to inoculate plants in the growth cabinets at $20 \mathrm{C} / 17 \mathrm{C}, 25 \mathrm{C} / 20 \mathrm{C}$ and $33 \mathrm{C} / 25 \mathrm{C}$. Inoculation was done by the double needle-prick method. Length of lesion $(\mathrm{cm})$ was measured 10, 14 and 20 days after inoculation.

The results, taken 2 weeks after inoculation, are presented in Figures 1,2 and 3. On IR8, which has no functional gene for resistance to bacterial leaf blight in the Philippines, the lesion developed well even at low temperature $(20 \mathrm{C} / 17 \mathrm{C})$ and showed remarkable increment, in response to the two virulent strains, PXO61 and PXO71 (Fig. 1), as temperature increased. Kinmaze, Kogyoku and Cas 209, which are also susceptible to the two strains, showed a similar trend to IR8 in lesion increment when temperature was increased. The degree of lesion development on those varieties was considerably higher than that on the resistant variety DV85 but differed from one temperature to another as shown in Figures 1 and 3.

Varieties with the $X a-4^{3)}$ gene for resistance such as IR20, IR26 and IR28 using incompatible strains PXO61 and PXO71 had generally shorter lesions compared to IR8,

\footnotetext{
* Hokuriku National Agricultural Experiment Station, Joetsu, Niigata 943-01, Japan (The senior author temporarily joined the Tropical Agriculture Research Center, from January to April, 1981) 、北陸農業試験場

** The International Rice Research Institute, Los Baños, Laguna, Philippines 国際稲研究所

1) Sidhu, G.S., Khush, G. S. and Mew, T. W. (1978). Theor. Appl. Genet. 53: 105-111. 2) Horino, O., Mew, T. W., Khush, G. S. and Ezuka, A. (1981). Ann. Phytopath. Soc. Japan 47:1-14. 3) Petpisit, V., Khush, G. S. and Kauffman, H. E. (1977). Crop Sci. $17: 551-554$.
} 

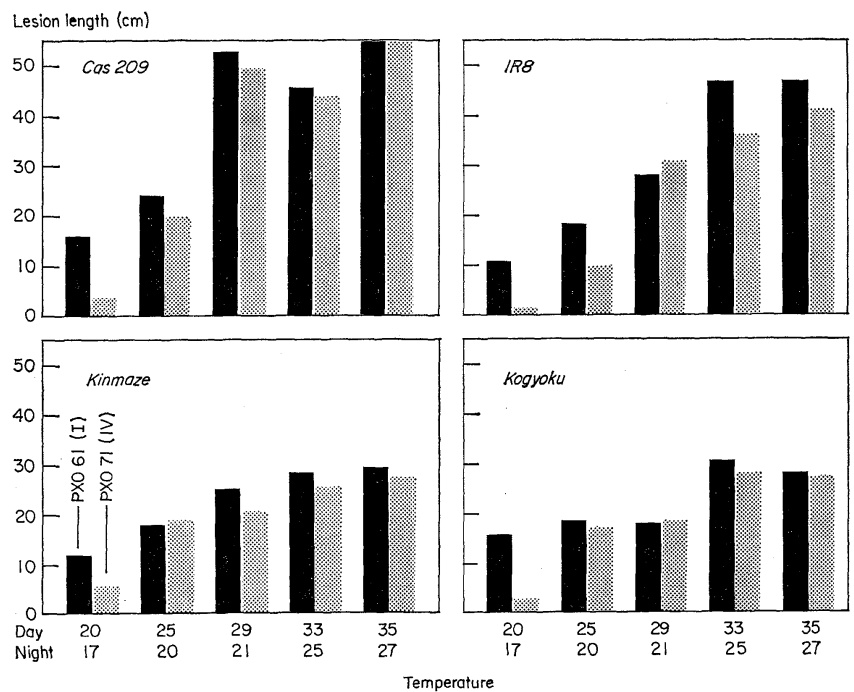

Fig. 1. Influence of temperatures on lesion development caused by two strains of Xanthomonas campestris pv. oryzae on four rice varieties compatible to bacterial leaf blight
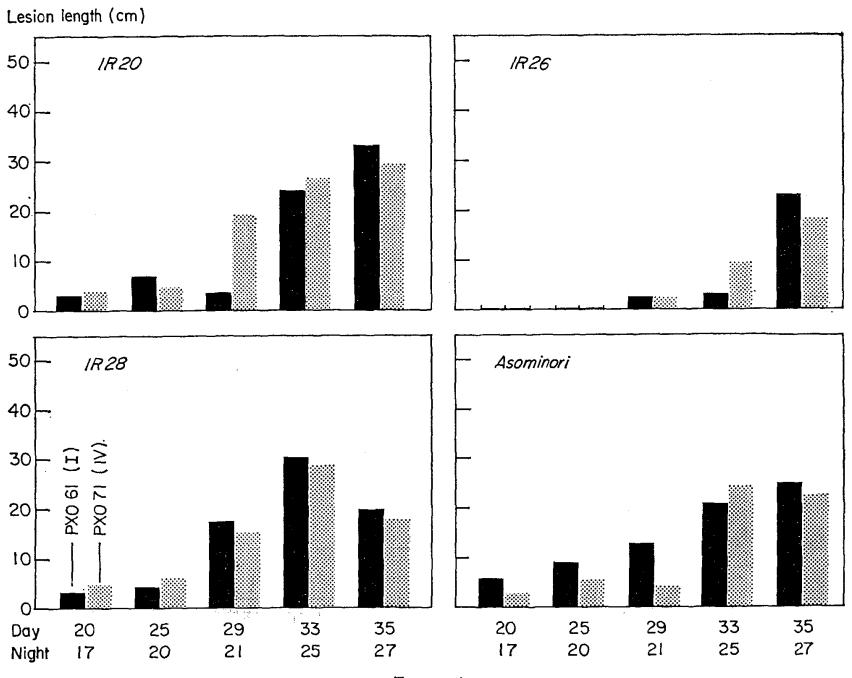

Fig. 2. Influence of temperatures on lesion development caused by two strains of Xanthomonas campestris pv. oryzae either virulent or less virulent to 4 rice varieties differing in resistance to bacterial leaf blight 

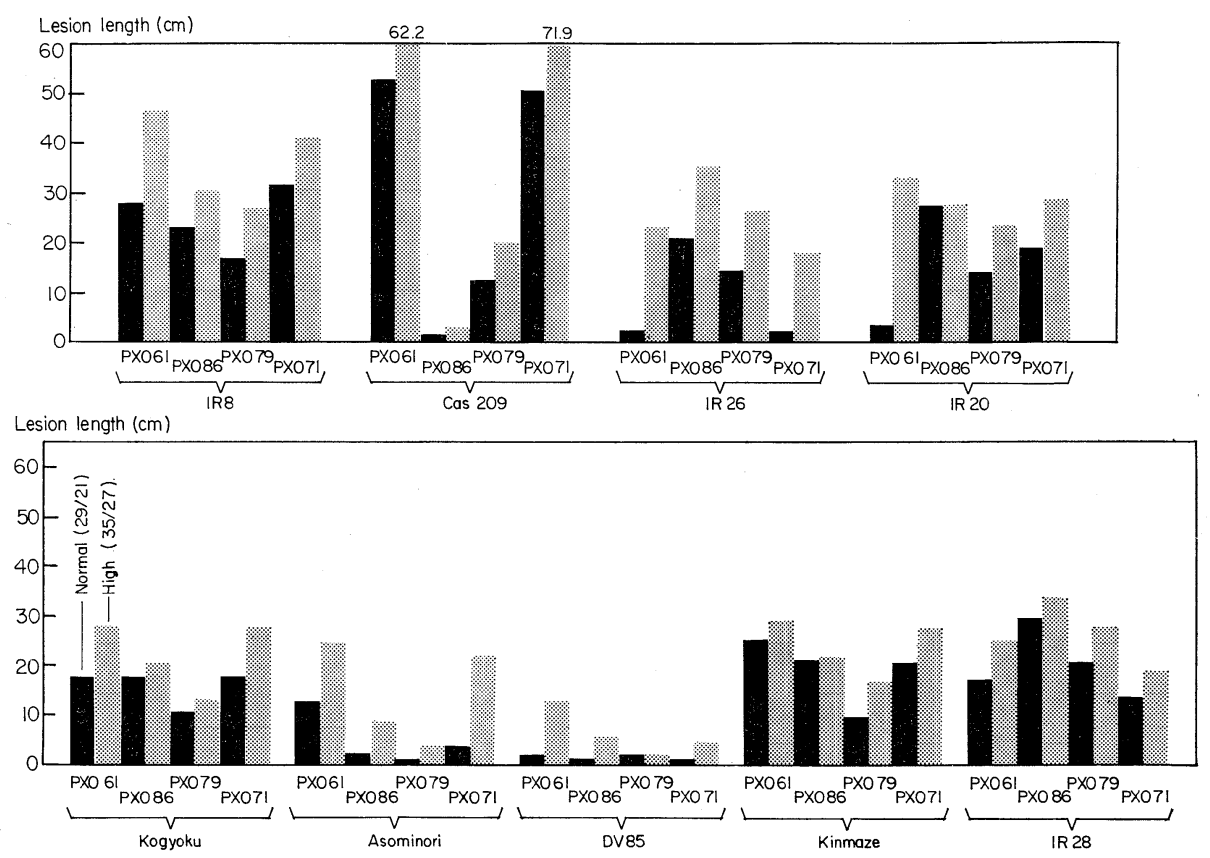

Fig. 3. Effect of 2 different temperatures on bacterial leaf blight lesion development produced by isolates differing in virulence on rice varieties with different genes for resistance

Cas 209 and Kinmaze except lesion development of IR20 at $35 \mathrm{C} / 27 \mathrm{C}$ (Figs. 1 and 2). IR26 had the shortest lesions to PXO61 and PXO71 at $20 \mathrm{C} / 17 \mathrm{C}, 25 \mathrm{C} / 20 \mathrm{C}, 29 \mathrm{C} / 21 \mathrm{C}$ and $33 \mathrm{C} / 25 \mathrm{C}$. Even at $20 \mathrm{C} / 17 \mathrm{C}$, lesions could still be visible on all varieties except on IR26. PXO61 generally caused slightly longer lesions on varieties susceptible to PXO61 and PXO71 at high temperature than PXO71 did.

Asominori of the Kogyoku varietal group exhibited shorter lesions to the compatible strains PXO61 and PXO71 than Cas 209 and IR8 at all temperatures except $20 \mathrm{C} / 17 \mathrm{C}$. This may be ascribed to the horizontal resistance of Asominori that was reported in $\mathrm{Japan}^{4,5)}$.

Figure 3 shows results from plants inoculated with 4 strains belonging to each bacterial group in glasshouses at normal $(29 \mathrm{C} / 21 \mathrm{C})$ and high $(35 \mathrm{C} / 27 \mathrm{C})$ temperatures. At normal temperature, lesions on susceptible varieties developed well as expected. However, lesions on IR20, IR26 and IR28, which carry $X a-4$ for resistance to PXO61 ${ }^{32}$, considerably increased at high temperature. Lesions on susceptible varieties exemplified by IR 8 and Kinmaze in response to the 4 bacterial strains developed well at both normal and high temperatures.

This study may partially indicate that disease reaction may be more severe in hightemperature condition. This may also explain why the occurrence and the development of the disease is more severe and widely distributed in the western part, such as in Kyushu region, where temperature is higher than in northern Japan.

4) Matsumoto, S., Sato, T. and Watanabe, B. (1977). Ann. Phytopath. Soc. Japan 43: 346 (Abstr.).

5) Sato, T., Matsumoto, S. and Watanabe, B. (1977). Ibid. 43: 347 (Abstr.). 
Longer lesions were exhibited at high temperature than at normal temperature on most of the varieties used except DV85. Even in incompatible combinations, lesions developed to some extent at high temperature. However, resistant or susceptible reactions of Cas 209 and DV85 to the 4 strains at different temperatures did not change (Fig. 3). At normal temperature, almost all varieties showed resistant or susceptible reactions which coincided with the findings of several researchers ${ }^{2,6}$.

High temperature appears to favor lesion development. The results agreed with earlier reports ${ }^{7,8,9)}$. Development of lesion on IR8 was favored in a wide range of temperatures from $25 \mathrm{C} / 20 \mathrm{C}$ to $35 \mathrm{C} / 35 \mathrm{C}^{8)}$. Horino and Yamada ${ }^{7)}$ also reported that high temperature $(34 \mathrm{C} / 34 \mathrm{C})$ appeared to enhance lesion development caused by the strain of Japanese bacterial group IV on both japonica and indica rices than $24 \mathrm{C} / 24 \mathrm{C}$ and $28 \mathrm{C} / 28 \mathrm{C}$. Mukoo et al. ${ }^{9)}$ investigated the degree of lesion development on inoculated plants at 3 different temperatures and indicated that higher temperature enhanced lesion development on rice plants.

The mechanism of the effect of high temperature on lesion development needs further studies. Whether it is independent of or dependent on high humidity is not well known. It is important to characterize the response of differential rice varieties to strains of $X$. campestris pv. oryzae at different temperatures and humidities.

We are grateful to Dr. N.C. Brady, former Director-General of IRRI, and Dr. S. Okabe, former Director-General of TARC, for their support and approval of this research. We also wish to express our sincere thanks to Dr. T. Kajiwara, former Associate Director for Research, TARC, and Mr. Z. Sato, Head of lst Laboratory of Plant Diseases, Hokuriku National Agricultural Experiment Station, for their kind arrangement to enable the senior author to stay at IRRI for 4 months.

(Received July 6, 1981)

6) Horino, O., Mew, T.W., Khush, G.S. and Ezuka, A. (1980). IRPS 53:1-11. 7) Horino, O. and Yamada, T. (1979). Proc. Assoc. P1. Prot. Hokuriku 27:12-18. 8) International Rice Research Institute (1975). In IRRI Annual Report for 1974. pp. 186-188. 9) Mukoo, H., Kusaba, T., Watanabe, M. and Tabei, H. (1957). Proc. Kanto P1. Prot. Soc. 4: 7-8. 